\title{
Barriers to Students' Academic Mobility in Russia
}

\author{
Tamara K. Rostovskaya ${ }^{1, *}$, Anastasiya S. Maksimova ${ }^{2}$, Nataliya M. Mekeko ${ }^{3}$, Svetlana N. Fomina ${ }^{4}$ \\ ${ }^{1}$ Institute of Socio-Political Research, Branch of the Federal Center of Theoretical and Applied Sociology of the Russian Academy of \\ Sciences (ISPR FCTAS RAS), Fotievoy Str., 6, Build. 1, Moscow, 119333, Russia \\ ${ }^{2}$ Russian State Social University, Wilhelm Pieck Str., 4, Build. 1, Moscow, 129226, Russia \\ ${ }^{3}$ Peoples' Friendship University of Russia (RUDN University), Miklukho-Maklaya Str., 6, Moscow, 117198, Russia \\ ${ }^{4}$ Russian State Social University, Wilhelm Pieck Str., 4, Build. 1, Moscow, 129226, Russia
}

Received January 14, 2020; Revised February 24, 2020; Accepted March 12, 2020

Copyright $\bigcirc 2020$ by authors, all rights reserved. Authors agree that this article remains permanently open access under the terms of the Creative Commons Attribution License 4.0 International License

\begin{abstract}
In the article, the concept of "academic mobility" is considered in the framework of internationalization of higher education as a process of moving participants (students and teachers) of the higher education process from one scientific and educational institution to another in order to exchange experience and acquire additional educational opportunities for a limited period of time or for temporary training. Special attention is paid to students' mobility, which is represented by both internal and external movement of students from one country to another, either between regions of the world or within a region. Information illustrating the dynamics of changes in the quantitative characteristics of international mobility in the country context is presented. Attention is drawn to the factors that affect the academic mobility of undergraduate and graduate students. The study uses statistical, analytical, and sociological methods. The study identified the types of academic mobility preferred by University students. A comparative analysis of the attitude of undergraduate and graduate students to various forms of academic mobility is presented. Differences were found depending on the place of residence. The ratio of students living in students' dormitories and those living with families was compared. It turned out that students who live in dormitories tend to take a more active part in academic mobility programs. Barriers that prevent students from participating in academic mobility programs are analyzed. The role of academic mobility in the formation and development of academic careers and career growth in the country context is revealed.
\end{abstract}

Keywords Academic Mobility, Barriers, Programmes of Education, Types of Educational Mobility

\section{Introduction}

Academic mobility and exchanges are not new, but also that for a long time they contributed to the internationalisation of higher education [1]. The global transition of higher education is characterized by increasing flows of institutions, programmes, students, and scholars as well as the changing relations between universities, governments, and the market. There are more than 2.5 million international students around the world, and this number is estimated to reach 7 million by 2020 [2].

The issue of students' mobility has been widely discussed as part of the internationalisation of higher education processes by many authors $[3,4]$. The academic mobility became more frequent and even was considered as "a kind of professional standard in some disciplines, because it helps to diffuse the formal and informal rules prevailing in other countries.

The internationally mobile students were defined by Kelo, Teichler and Wachter as "students who cross national borders for the purpose of, or in the context of, their studies" [5]. Concerning the types of academic mobility, students' mobility can be both an inward and outward movement of students from one country to another either between regions of the world or within a region... Conceptualising students' mobility in higher education has been challenging as students' movement across national borders have sometimes been confused with other concepts like migration and 'brain drains'. But, the duration of stay of international students in the host country can be considered as a determining factor for understanding and using the terms related to students' mobility. Accordingly, students' mobility can be for a short period of time as within 'exchange programmes' or it can be for the whole programme as 'study abroad'. Thus, international students' mobility can be described as students that cross borders and stay in another country to take either short- or long-term training in higher education either within a region, intra-regional or among countries across different regions inter-regional [6]. 
Table 1. Integral classification of student long-term mobility forms [8]

\begin{tabular}{|c|c|c|c|c|}
\hline \multirow{2}{*}{$\begin{array}{l}\text { Purpose of } \\
\text { Mobility }\end{array}$} & \multicolumn{4}{|c|}{ Institutional form of mobility } \\
\hline & Free-movers & $\begin{array}{l}\text { State scholarship } \\
\text { programmes }\end{array}$ & Inter-university co-operation programmes & Agent support \\
\hline $\begin{array}{l}\text { Degree } \\
\text { mobility }\end{array}$ & \multicolumn{2}{|c|}{$\begin{array}{l}\text { Degree mobility of all levels: } \\
\text { bachelor, master, } 5 \text {-year specialist } \\
\text { programmers, } \quad \mathrm{PhD} \text { and } \\
\text { post-doctoral programmes }\end{array}$} & $\begin{array}{l}\text { Degree mobility of postgraduate levels: } \\
\text { bachelor, master, 5-year specialist } \\
\text { programmers, } \mathrm{PhD} \text { and post-doctoral } \\
\text { programmes }\end{array}$ & $\begin{array}{l}\text { Degree mobility of all levels: } \\
\text { bachelor, master, } 5 \text {-year specialist } \\
\text { programmers, } \mathrm{PhD} \text { and post-doctoral } \\
\text { programmes }\end{array}$ \\
\hline
\end{tabular}

Table 2. Integral classification of student short-term mobility forms [8]

\begin{tabular}{|c|c|c|c|c|}
\hline \multirow{2}{*}{$\begin{array}{l}\text { Purpose of } \\
\text { Mobility }\end{array}$} & \multicolumn{4}{|l|}{ Institutional form of mobility } \\
\hline & Free-movers & $\begin{array}{ll}\begin{array}{l}\text { State } \\
\text { programmes }\end{array} & \text { scholarship } \\
\end{array}$ & $\begin{array}{l}\text { Inter-university } \\
\text { programmes }\end{array}$ & Agent support \\
\hline $\begin{array}{l}\text { Credit } \\
\text { mobility }\end{array}$ & & $\begin{array}{l}\text { Credit mobility in partner } \\
\text { universities, network } \\
\text { university programmes }\end{array}$ & $\begin{array}{l}\text { Multilateral joint and double degree } \\
\text { programmes of all levels }\end{array}$ & \\
\hline $\begin{array}{l}\text { Non-degree } \\
\text { mobility }\end{array}$ & $\begin{array}{l}\text { Summer/Winter schools, } \\
\text { short trainings } \begin{array}{r}\text { and } \\
\text { internships, language courses }\end{array}\end{array}$ & $\begin{array}{l}\text { Summer/Winter schools, } \\
\text { short trainings and } \\
\text { internships, language } \\
\text { courses }\end{array}$ & $\begin{array}{l}\text { Summer/Winter schools, short } \\
\text { trainings and internships, language } \\
\text { courses based on inter-university } \\
\text { partnership agreements }\end{array}$ & $\begin{array}{l}\text { Internships and } \\
\text { language } \\
\text { courses }\end{array}$ \\
\hline
\end{tabular}

Students move from one country to another for a full degree, but also to a credit mobility, whereby students spend a period (in general between 3 and 12 months) of their study in another country and transfer their earned credits to their home degree [7].

Vatolkina, Starozhuk and Fedotkina described the integral classification forms of students' mobility (Table 1, Table 2) [8].

The table represents the two types of mobility: long-term mobility and short-term mobility. Degree mobility can be considered within long-term mobility; credit and non-degree mobility can be considered as short-term mobility.

In a broad sense, the term "academic mobility" means the process of moving of participants (students of teachers) in a higher education process from one research and educational institution to another, in order to exchange experience and acquire additional educational opportunities within some limited period of time or with the purpose of temporary teaching.

The definition of academic migration was completed over time. Academic mobility is usually perceived and discussed as a positive phenomenon - as a prerequisite for building a competitive and successful economy and quality science. Academic mobility has now become essential to building a successful academic career in many research domains.

Mobility is now regarded as a central feature of academic careers by research institutions, policies as well as individual researchers. It is usually discussed in positive terms, both at the policy and individual level. Often regarded as 'the fifth freedom' in the EU (together with the movement of people, capital, goods and services), academic mobility is seen as one of the prerequisites for building competitive science, and relatedly for building a knowledge - and innovation-based economy $[9,10]$.

At the individual level, academic mobility is associated with improving qualifications, developing competences, 'broadening horizons' and building personal networks [10, 11]. In many fields, mobility has become a necessary precondition for the successful launch of an academic career and for career progression. This trend has slowly started to expand from the natural and technical sciences to the social sciences and humanities [12].

For higher education institutions, a high level of mobility among students - incoming and outgoing-is a sign of prestige and quality [13, 14], not in the least because internationalisation nowadays is an important indicator in global rankings [15].

Many countries have already successfully implemented many programmes to promote academic mobility, including such programmes as Erasmus Mundus, DAAD, Tempus, Fulbright Programme, etc. [16, 17]. As a rule, the implementation of such programmes allows participating countries to receive positive socio-economic, scientific and demographic effects. Taking into account the huge potential of Russian higher education, the formation and implementation of such a programme (with amendments to the realities of Russian society and the state of the Russian science) will expand the boundaries and create unique opportunities for the development of academic mobility in Russia [18].

In the European Union (EU), international students' mobility as part of the home degree has steadily increased in the past years [19]. Erasmus is the largest mobility student exchange scheme for higher education in Europe and the flagship programme of the EU [20].

Souto-Otero, Huisman, Beerkens, de Wit and Vujić highlighted the barriers that higher education students face in relation to studying abroad [20]. Most research has been carried out on the problems and barriers faced by those students who go abroad rather than on the problems of those who do not [21-23]. Neither has there been a sufficient focus in research on the differences in students' 
achievements between participants and non-participants. Research has shown that many students, interested in and actually signing up for Erasmus, eventually do not participate [24-26].

The factors or barriers explored in the study of Souto-Otero, Huisman, Beerkens, de Wit and Vujić were of five types: financial barriers, barriers related to higher education system comparability, awareness and information barriers, personal background, and social background [20]. More than 20 individual barriers related to those five dimensions were highlighted by the research of Souto-Otero, Huisman, Beerkens, de Wit and Vujić [20].

The lack of participation in the Erasmus + academic mobility seems to be more a process of self-exclusion on the part of the students, than of selection on the part of the institutions, as suggested by Teichler [4]. Therefore, it is important to know the obstacles faced by students who decide not to participate, since it has been detected that the importance of these barriers seems to change from country to country [27].

In addition, there are important differences in participation depending on the scope of study, being the social sciences, business and law degrees, those that have a higher percentage of mobility, compared to health sciences and services, which would occupy the 4 th place according to 2013-14 data [26].

The requirement to study in a language other than English can be a serious barrier [28]. Some researchers indicated that insufficiently good grades to study abroad can be a problem, as well as the lack of knowledge about what is involved in the exchange, lack of students' confidence, the inflexibility of degrees, and concerns about eligibility for loans and allowances. Sanchez, Fornerino and Zhang suggest that students had the following barriers to study abroad: family, financial, psychological (related to aspects such as feelings for students' own country and fear of new places), and social (related to friends and family)-although they experienced these to varying degrees [29].

A sense of the place in which we live is often related to our sense of personal identity since much of what we are depends upon where we live and the experiences that we have had there [30, 31]. Consequently, individuals usually develop very strong sentimental and emotional attachments to the places in which they spend their lives [32]. This attachment has also been referred to as "Place Identity" [31]; this term describes the relationship between people and places by emphasising the role of place in moulding the individual's sense of self-identity.

Community sentiments of attachment and identity increase with years of residence [33,34], and vary at different times of life. A general finding is that people who have resided in the community the longest tend to have higher scores of attachment and Place Identity [35]. This seems to be entirely logical.
In this sense, residential mobility (particularly voluntary mobility) may represent an adaptive strategy for modifying some aspects of one's life and identity. Moreover, residential mobility during late adolescence and young adulthood may be a contributing factor to the development of autonomy from the family [36, 37].

In the context of increasing globalization, national education and science systems are becoming more open to the world and contacts with foreign partners. The Russian system of education and science is no exception [38-40].

Russian universities develop different forms of co-operation with foreign universities, the students can take part in exchange programmes between universities, take part in international educational projects, or join a Russian mobility programme of the Ministry of Education. The legal basis for the functioning of this academic mobility programme are bilateral agreements on scientific and educational co-operation of Russia.

The Russian government supports the outgoing mobility in the following forms:

1. "Global education" is a project started in 2014 and is aimed at the development of outbound student mobility. The list of foreign partner universities of the programme includes more than 288 of the best universities from 32 countries. Participants of the programme receive financial support from the state for the full payment for the entire course of study, accommodation and living costs.

2. The programme of scholarships of the President of the Russian Federation to study abroad offers 40 scholarships to bachelor and master degree students and 60 scholarships to $\mathrm{PhD}$ students to study abroad for 12 months at a foreign University.

3. The Ministry of Education and Science of the Russian Federation provides scholarships for students, postgraduates, university research and teaching staff annually for short courses or internships at the foreign universities in the framework of inter-governmental agreements of the Russian Federation.

4. The Academic Mobility Project of the Mikhail Prokhorov Foundation offers the opportunity for senior students, postgraduate students and young teachers under 35 years to take part in scientific conferences and seminars, work in archives and libraries, internships in scientific institutions abroad for a period of not more than 2 weeks. The fund supports the participants from the Ural, Siberian and far Eastern Federal districts, Voronezh, Lipetsk, Tambov, Ryazan region, Perm Krai and Togliatti.

5. Student mobility can be supported by those network universities that implement joint educational programmes with Russian universities.

The objectives of this article are:

- determination of the types of academic mobility preferred by university students; 
- $\quad$ analysis of the current situation of academic mobility in the Russian Federation based on the implementation of the programme of academic mobility (data from the Ministry of Education of the Russian Federation);

- Identifying barriers to academic mobility among undergraduate and graduate students at technical university (Moscow State University of Food Production).

- Identifying the differences according to Place Identity (PI) residential conditions (native vs. temporary residents).

\section{Method}

\subsection{Background Information}

The results of the implementation of the programme of outgoing academic mobility on the basis of information were provided on the website of the Ministry of Education of the Russian Federation. The programmes of academic mobility provided by the Ministry of Education together with exchange programmes of partner Universities are the main forms of the educational mobility at the university.

The experiment was conducted at Moscow State University of Food Production. Information on academic mobility was presented on the university website, but it was obvious that not all students were familiar with this information. For first-year students, this information was new, and older students were already fully or partially aware of it. Some of the students were native students born in Moscow or the surroundings, the other students came from different areas of Russia and were currently resident in Moscow during their period of study.

Place Identity was assessed by the item developed by Pretty, Chipuer and Bramston [41]. The confirmation was used to identify the identity for the home place.

\subsection{Participants}

291 students of Moscow State University of Food Production were surveyed, 183 of them are the students of a Bachelor programme of study (111 - females, 72 males) and 108 students are on their Master Programme (50 females, 58 males). The directions of study of the students related to food technology and service. All the students agreed to answer the questions voluntarily and anonymously.

\subsection{Materials}

The participants were asked to answer the questions about their age, gender, degree course and year of university without indicating their names:

1) Please, indicate the information about yourself:
- You are a student of a Bachelor programme, the year of study 1, 2, 3, 4 (please, underline)

- You are a student of a Master Programme, year of study 1, 2 (please, underline)

Gender - male, female (please, underline)

- Is Moscow your native city? Yes, No (please, underline)

- Do you live in a hostel?

2) Do you know about academic mobility programmes?

3) Are you interested in a short-term foreign language study programme? (language study course)

4) Are you interested in a short-term programme of study in the specialty? (credit mobility programme)

5) Are you interested in the programme of long-term training in the specialty? (a full degree course)

6) Do you know about the European Credit Transfer and Accumulation System - ECTS?

7) Do you think that your level of English will be relevant for study abroad?

Do you have the international certificate confirming the level of your English language?

What other languages, apart of English, can you use effectively? (i.e. fluent)

8) Would you like to participate in the academic mobility programme?

9) Indicate which factors of studying overseas are important for you to make a decision on studying abroad. The degree of importance of the factor:

1 - Not at all important, 2 - low importance, 3 moderately important, 4 -very important, 5 -extremely important.

Items were constructed on the basis of a literature review and items in earlier surveys.

10) Think about your native home residence and please indicate your agreement with the following statement:

"I would rather live in a different town / city. This is not the best place for me" using five levels of agreement, that the statement is truthful: $1=$ definitely untrue; $2=$ untrue; 3 = undecided; $4=$ true; $5=$ very true

The investigations concerning the effect of gender on the students' answers were not conducted.

\subsection{Analysis}

Arithmetical mean is counted for each question, standard deviation and standard error are written in brackets.

$$
t=\frac{M_{1}-M_{2}}{\sqrt{m_{1}^{2}+m_{2}^{2}}}
$$


$M_{1}$ is an arithmetical mean for the first group. $M_{2}$ is an arithmetical mean for the second group.

$\mathrm{m}_{1}$ is a standard error for the first group. $\mathrm{m}_{2}$ is a standard error for the second group.

If ' $\mathrm{t}$ ' is small, the null hypothesis (of no difference between the participants' performance in the two conditions) is accepted.

If ' $t$ ' is large, the null hypothesis is rejected (two sets of data only partially overlap which means that the independent variable had a noticeable effect on the participants).

Critical value of ' $t$ ' for 183 participants is 1.973 . Critical value of ' $t$ ' for 108 participants is 1.984 . Critical value of probability is 0.05 .

\section{Results}

In 2016, the Ministry of Education and Science of Russia sent 528 people for training and short-term internships $(50 \%$ more than in 2015) to 21 countries. Table 3 presents information illustrating the dynamics of changes in the quantitative characteristics of international mobility.

Table 4 represents the attitude of the students to different forms of participation in educational programmes of mobility.

Table 3. The distribution of the approved number of applications by country (the data is from http://im.interphysica.su/)

\begin{tabular}{|c|c|c|c|c|c|}
\hline No & Country & $\begin{array}{c}\text { Applications approved in } \\
2014 \Gamma \text {. }\end{array}$ & $\begin{array}{c}\text { Applications approved in } \\
2015 \Gamma \text {. }\end{array}$ & $\begin{array}{c}\text { Applications approved in } \\
2016 \text { г. }\end{array}$ & Total amounts \\
\hline 1 & China & 129 & 141 & 175 & 445 \\
\hline 2 & Hungary & 7 & 8 & 103 & 118 \\
\hline 3 & Serbia & 23 & 31 & 27 & 81 \\
\hline 4 & Czech & 11 & 22 & 45 & 78 \\
\hline 5 & Norway & 25 & 13 & 34 & 72 \\
\hline 6 & Slovakia & 12 & 30 & 30 & 72 \\
\hline 7 & Vietnam & 12 & 18 & 22 & 52 \\
\hline 8 & Romania & 13 & 16 & 18 & 47 \\
\hline 9 & Italy & 16 & 13 & 16 & 45 \\
\hline 10 & Bulgaria & 15 & 13 & 11 & 39 \\
\hline 11 & Denmark & 14 & 12 & 8 & 34 \\
\hline 12 & Belgium & 11 & 6 & 6 & 23 \\
\hline 13 & Mongolia & 6 & 3 & 14 & 23 \\
\hline 14 & Austria & 3 & 5 & 6 & 14 \\
\hline 15 & France & 3 & 3 & 6 & 12 \\
\hline 16 & Turkey & 0 & 10 & 0 & 10 \\
\hline 17 & Kuwait & 2 & 3 & 4 & 9 \\
\hline 18 & Poland & 3 & 0 & 0 & 3 \\
\hline 19 & $\begin{array}{c}\text { Brunei } \\
\text { Darussalam }\end{array}$ & 0 & 1 & 1 & 2 \\
\hline 20 & Mexico & 0 & 1 & 0 & 1 \\
\hline 21 & Slovenia & 0 & 1 & 0 & 1 \\
\hline
\end{tabular}

Table 4. The preferable forms of participation in the forms of academic migration (it was possible to indicate more than one option)

\begin{tabular}{|l|c|c|c|c|}
\hline & $\begin{array}{l}\text { Students of the } \\
\text { Bachelor programme, } \\
1-2 \text { year of study, } \%\end{array}$ & $\begin{array}{l}\text { Students of the } \\
\text { Bachelor programme, } \\
3-4 \text { year of study, } \%\end{array}$ & $\begin{array}{l}\text { Students of the } \\
\text { Master programme, } \\
\text { 1 year of study, } \%\end{array}$ & $\begin{array}{l}\text { Students of the } \\
\text { Master programme, 2 } \\
\text { year of study, } \%\end{array}$ \\
\hline $\begin{array}{l}\text { The number of students interested } \\
\text { in a short-term foreign language } \\
\text { study course }\end{array}$ & 33 & 15 & 16 & 11 \\
\hline $\begin{array}{l}\text { The number of students interested } \\
\text { in a short-term credit mobility } \\
\text { programme (up to a year) }\end{array}$ & 54 & 43 & 31 & 22 \\
\hline $\begin{array}{l}\text { The number of students interested } \\
\text { in a full degree course) }\end{array}$ & 32 & 47 & 53 & 22 \\
\hline $\begin{array}{l}\text { The number of students who are } \\
\text { aware about ECTS }\end{array}$ & 4 & 27 & 39 & 42 \\
\hline $\begin{array}{l}\text { The number of students } \\
\text { considering participation in the } \\
\text { programme }\end{array}$ & 86 & 83 & 73 & 56 \\
\hline
\end{tabular}


Table 5. The answers of the students of Bachelor and Master programme about their knowledge of the foreign languages (Do you think that your level of English will be relevant for study abroad?)

\begin{tabular}{|c|c|c|}
\hline \multirow{2}{*}{ The language } & $\begin{array}{c}\text { Bachelor students, \%/ } \\
\text { The number of students with international Certificate }\end{array}$ & $\begin{array}{c}\text { Master students, \%/ } \\
\text { The number of students with international Certificate }\end{array}$ \\
\hline English & $15 / 5$ & $22 / 3$ \\
\hline German & $6 / 1$ & $6 /-$ \\
\hline French & $3 /-$ & $2 /-$ \\
\hline Italian & $2 /-$ & $1 /-$ \\
\hline
\end{tabular}

The different factors of attitude to obstacles and barriers considered by the students of Bachelor programme are represented in Table 5.

\section{Discussion}

The table 3 shows different countries offering different amount of places for Russian students.

Table 3 shows the distribution of quantitative indicators of international exchanges by country. China is leading by a large margin (175 internships), Hungary is in second place (103 approved internships). The following 6 places are occupied by the rest of Europe (136 internships). The third place is occupied by the Czech Republic (45 internships), the fourth - Norway (34 internships), the fifth - Slovakia (29 internships + one extension), the sixth Serbia (27 internships). In total across the countries of Europe - 312 internships. In the European countries of the former socialist camp 236 internships were conducted.

According to the Ministry of Education, the largest competition is in France (4.75), in Italy (3.38), Austria (2.8), Belgium (2.17), Norway (1.87). A competition for more than 1 person per seat took place only for two European former socialist countries: Slovakia (1.88) and Serbia (1.2). Separate situation with China: the largest number of applications submitted (158) and the competition of 1.22 people per seat. The last 4 places divided as follows: Mongolia (0.25), Hungary (0.24), Vietnam (0.22), Poland (0.08) - all former socialist countries.

Thus, it can be concluded that the co-operation programmes are offered mainly by the countries of the former socialist camp, at the same time as the social need is applicable to internships in the countries of Western Europe. An entirely separate situation exists in China: a large number of proposed places and applications are combined here.

There is an imbalance between the proposals in the framework of the sectoral programme of academic mobility and demand from the educational community of Russia.

The Ministry of Education and Science of the Russian Federation provides opportunities for the citizens of the Russian Federation to receive educational services (undergo short-term internships) in foreign countries. The purpose is to gain teaching and research experience in foreign countries.

The growing number of students worldwide is the main trend in higher education in recent decades, which has proven that it is public good. In the 70s of the last century, there were 28.5 million students in the three-level education system in the world, of which about $62 \%$ were men. By 2000, the number of students had grown to 100 million. Since the beginning of the 21 st century, education in the world has been experiencing the most noticeable period of growth in popularity in its history. By 2005, the number of students had grown to 139 million people, by 2010 to 181 million people, and in 2012 there were already 196 million students. According to the forecasts of the UNESCO Institute for Statistics, by 2025 the number of students of the three-tier education system will increase to 263 million people [42].

The internationalisation of higher education is a political task of the governments of the countries concerned. Internationalisation stimulates the quality of education, the diversity of education and the free exchange of educational resources. This, in turn, generates opportunities for students to experience the 'global village' together with an appreciation for other cultures - one of the many 'hidden' benefits [43].

As in the case of higher education, scientific work is also undergoing a process of internationalisation. This is facilitated by the creation of regional research clusters and international competition for funding research activities. Many global challenges, such as climate change and epidemic diseases, require global solutions. Therefore, scientists around the world are expanding co-operation in an attempt to create a knowledge-based society.

For the effective implementation of plans for the scientific integration of the world community, an important factor is the availability of conditions for the implementation and development of academic mobility. After all, it becomes possible to create a single scientific space and efficient use of educational resources [44].

The results of the Table 4 show that short-term language courses are more popular among students of the Bachelor programme of the 1 and 2 years of study (33\%). These students study English during the first two years of education, they are interested in the English language and are looking for an opportunity to improve it. There is a rather sharp decrease in the amount who wish to practice 
their language proficiency abroad while the other forms of academic mobility became more popular. A short-term credit mobility programme (up to a year) attracts the students of the Bachelor programme more than students of the students of Master programme (54\% and $43 \%)$. This type of mobility is popular, because it allows the students to continue the education in the home institute while taking part in the programme of educational mobility. The students indicated that short-time programmes (from 3 months to a year) are more interesting. Such programmes are offered by foreign universities, sometimes the period of study varies from one term to a year. The latter is true for Master programmes in foreign universities that offer the students to take one year of an educational programme.

A full degree course is less popular among the students of the years 1 and 2 of study on the Bachelor programme, because the programme means the transfer to a different country and the students have not yet developed new circles of friends. Usually the first year of study is a very challenging time and students are less eager to consider education abroad especially for any education programme needing a long period of time.

The data show that the students have very little information about the credit system and ECTS.

The system of credits is used in Russian universities but very few students, especially at their first years of study, know about the purpose of the system. The students of the first year are less aware about it (14\%), while the Master students have more information about it (42\%).

The young people are curious and wish to take different opportunities in life.

A huge number of students $(86 \%)$ indicated their interest in the programmes of educational mobility. Their interest keeps relatively high through the course of study and only the students of the $2^{\text {nd }}$ year of the Master level of study showed their lower intention to pursue the programme of mobility.

The table 5 shows the results of self-assessment of the levels of foreign language and the expectancy that this level will be relevant for education abroad. The majority of students of Bachelor and Master levels of education indicated that they knew English well (15\% and 22\%), German $(6 \%$ and $6 \%)$, French $(3 \%$ and $2 \%)$ and Italian $(2 \%$ and $1 \%)$. Very few students had the international Certificate.

Table 6 shows the factors that are important for undergraduate students (native students and students- resident in Moscow) for education abroad. The data showed that the most important factor for all students is the financial issue (4.82 and 4.89). Also, important factors are a requirement to study in a language other than English (4.73 and 4.32), the level of mastering English (4.71 and 4.73), information about the programme and the university (4.61 and 4.62).

However, there is a difference in attitude towards learning from native students and students - resident in Moscow. The separation from the family and friends and requirement to study in a language other than English were more important for visiting students. The existing work in Russia is more important for non-Muscovites than citizens of Moscow.

Table 7 shows the factors of importance students of the Master program. The most important factors are integration of programmes at home and abroad (4,94 and $4,95)$, financial issues $(4,86$ and 4,82$)$, information about the programme and the university $(4,90$ and 4,92$)$, the level of mastering English $(4,92$ and 4,94) and requirement to study in a language other than English $(4,76$ and 4,35$)$. There is a different attitude of the students to any requirement to study in a language other than English $(T=2,066)$. It shows that mobile students from other regions look at this barrier as not so difficult. They indeed agree to study to start a Master course in China with a special pre-programme language course. A Master's degree programme in China usually involves learning Chinese for one year, and such instructions are in Chinese.

Undergraduate education is also possible with knowledge of Chinese, and, as China continues to develop, fluency of the two major languages will be a valuable asset to those students who successfully gain fluency.

The non-resident students highlighted the importance to the quality of education and the university's rating, but at the same time, they are ready to choose a programme from the range of programmes offered. A number of training programmes are designed to study the national language (Norwegian, Mongolian, Vietnamese) and provide for the continuation of the training programme that had been started in Russia.

The Place Identity related to the home town was higher among non-native students than native (Table 8). It means that non-resident students are more mobile, they are less attached to their families, because they developed their independence when they left home for a new place of living in Russia. 
Table 6. The factors of importance for the students of Bachelor programme (Home students vs. Students of residential mobility)

\begin{tabular}{|c|c|c|c|c|}
\hline & & $\begin{array}{l}\text { The factor of importance } \\
\text { (bachelor programme) } \\
\text { Students from home town }(n=109)\end{array}$ & $\begin{array}{l}\text { Students of residential } \\
\text { mobility }(\mathrm{n}=74)\end{array}$ & $\begin{array}{l}\text { Student's t-test } \\
p=0,05\end{array}$ \\
\hline 1 & Financial issues & $4,82(1,06 ; 0,10)$ & $4,89(1,03 ; 0,12)$ & $0,448<1,973$ \\
\hline 2 & The county of study & $4,42(1,11 ; 0,11)$ & $4,38(1,02 ; 0,12)$ & $0,246<1,973$ \\
\hline 3 & $\begin{array}{l}\text { Integration of programmes at home } \\
\text { and abroad }\end{array}$ & $4,35(1,07 ; 0,10)$ & $4,37(1,12 ; 0,13)$ & $0,122<1,973$ \\
\hline 4 & Accommodation abroad & $4,32(0,99 ; 0,09)$ & $4,36(1,05 ; 0,12)$ & $0,267<1,973$ \\
\hline 5 & $\begin{array}{l}\text { Information about the programme and } \\
\text { the university }\end{array}$ & $4,61(1,12 ; 0,11)$ & $4,62(0,97 ; 0,11)$ & $0,064<1,973$ \\
\hline 6 & $\begin{array}{l}\text { Requirement to study in a language } \\
\text { other than English }\end{array}$ & $4,73(1,03 ; 0,10)$ & $4,32(1,06 ; 0,12)$ & $2,625>1,973$ \\
\hline \multirow[t]{4}{*}{7} & Personal reasons: & & & \\
\hline & The existing work in Russia & $2,43(1,07 ; 0,10)$ & $4,37(0,97 ; 0,11)$ & $13,049>1,973$ \\
\hline & Family (separation from the family) & $4,56(1,10 ; 0,11)$ & $3,14(1,07 ; 0,12)$ & $8,723>1,973$ \\
\hline & Separation from friends & $3,21(1,02 ; 0,10)$ & $2,82(0,99 ; 0,12)$ & $3,905>1,973$ \\
\hline 8 & The level of mastering English & $4,71(0,98 ; 0,09)$ & $4,73(1,06 ; 0,12)$ & $0,133<1,973$ \\
\hline
\end{tabular}

Table 7. The factors of importance for the students of Master programme (Home students vs. Students of residential mobility)

\begin{tabular}{|c|c|c|c|}
\hline & $\begin{array}{l}\text { The factor of importance } \\
\text { (master programme) } \\
\text { Students from home town }(n=64)\end{array}$ & $\begin{array}{l}\text { Students of residential } \\
\text { mobility }(\mathrm{n}=44)\end{array}$ & $\begin{array}{l}\text { Student's t-test } \\
p=0,05\end{array}$ \\
\hline Financial issues & $4,86(1,01 ; 0,13)$ & $4,82(0,98 ; 0,15)$ & $0,202<1,984$ \\
\hline The county of study & $4,11(1,12 ; 0,14)$ & $4,02(1,06 ; 0,16)$ & $0,423<1,984$ \\
\hline $\begin{array}{l}\text { Integration of programmes at home and } \\
\text { abroad }\end{array}$ & $4,94(1,05 ; 0,13)$ & $4,95(1,02 ; 0,15)$ & $0,050<1,984$ \\
\hline Accommodation abroad & $4,31(1,07 ; 0,13)$ & $4,30(1,01 ; 0,15)$ & $0,050<1,984$ \\
\hline $\begin{array}{l}\text { Information about the programme and the } \\
\text { university }\end{array}$ & $4,90(0,99 ; 0,12)$ & $4,92(1,05 ; 0,16)$ & $0,100<1,984$ \\
\hline $\begin{array}{l}\text { Requirement to study in a language other } \\
\text { than English }\end{array}$ & $4,76(1,03 ; 0,13)$ & $4,35(1,01 ; 0,15)$ & $2,066>1,984$ \\
\hline \multicolumn{4}{|l|}{ Personal reasons: } \\
\hline The existing work in Russia & $4,51(1,01 ; 0,13)$ & $4,92(1,07 ; 0,16)$ & $1,989>1,984$ \\
\hline Family (separation from the family) & $3,49(1,09 ; 0,14)$ & $3,06(0,97 ; 0,15)$ & $2,096>1,984$ \\
\hline Separation from friends & $4,83(1,08 ; 0,14)$ & $4,38(1,12 ; 0,17)$ & $2,043>1,984$ \\
\hline The level of mastering English & $4,92(1,03 ; 0,13)$ & $4,94(1,10 ; 0,17)$ & $0,093<1,984$ \\
\hline
\end{tabular}

Table 8. The index of Place Identity between Bachelor and Master students

\begin{tabular}{|c|c|c|c|}
\hline \multicolumn{4}{|c|}{ The change of the place of Identity between Bachelor students } \\
\hline \multirow[t]{2}{*}{ Place Identity (PI) } & $\begin{array}{l}\text { The factor of importance } \\
\text { (bachelor programme) } \\
\text { Students from home town }(n=109)\end{array}$ & Students of residential mobility $(\mathrm{n}=74)$ & Student's t-test $\mathrm{p}=0,05$ \\
\hline & $2,28(0,93 ; 0,09)$ & $2,61(0,95 ; 0,11)$ & $2,322>1,973$ \\
\hline \multicolumn{4}{|c|}{ The change of the place of Identity between Master students } \\
\hline \multirow[t]{2}{*}{ Place Identity (PI) } & $\begin{array}{l}\text { The factor of importance } \\
\text { (bachelor programme) } \\
\text { Students from home town }(n=109)\end{array}$ & Students of residential mobility $(\mathrm{n}=74)$ & Student's t-test $\mathrm{p}=0,05$ \\
\hline & $1,68(0,98 ; 0,12)$ & $2,85(0,96 ; 0,14)$ & $6,345>1,984$ \\
\hline
\end{tabular}


It was important to look at the fears and apprehension of students, which influence their decision to take, or/not to take, part in the educational programme abroad. The main reasons hindering the development of international educational co-operation in this area are the lack of information, their lack of confidence about the level of the English language that will be relevant for academic purposes, and the need for knowledge of national languages.

To increase participation, the focus should be on improving information about the international programmes and about the different sides, concerning education abroad.

\section{Acknowledgments}

The research was conducted with the support of RFBR (project № 18-29-15043).

\section{REFERENCES}

[1] P. G. Altbach. Perspectives on Internationalizing Higher Education, International Higher Education, Vol. 27, 6-8, 2002.

[2] Q. Chen. Higher Education Transition and Academic Mobility in China, in Globalization and Transnational Academic Mobility, East-West Crosscurrents in Higher Education, Springer, Singapore, 2017.

[3] J. Knight, E. T. Woldegiorgis. Academic Mobility in Africa, in Regionalization of African Higher Education, African Higher Education: Developments and Perspectives, Sense Publishers, Rotterdam, 2017.

[4] U. Teichler. Temporary study abroad: The life of ERASMUS students, European Journal of Education, Vol. 39, No. 4, 395-408, 2004.

[5] M. Kelo, U. Teichler, B. Wachter (Eds.). Eurodata: Student mobility in European higher education, Lemmens, Bonn, Germany, 5, 2006.

[6] E. T. Woldegiorgis, M. Doevenspeck. Current trends, challenges and prospects of student mobility in the African higher education landscape, International Journal of Higher Education, Vol. 4, No. 2, 105, 2015.

[7] H. De Wit. Changing dynamics in international student circulation: Meanings, push and pull factors, trends and data, in The dynamics of international student circulation in a global context, Sense Publishers, Rotterdam, Netherlands, 15-48, 2008.

[8] N. Vatolkina, E. Starozhuk, O. Fedotkina. Education internationalization through student mobility in Russian Federation Proceedings of ICERI2018 Conference 12th-14th November 2018, Seville, Spain. DOI:10.21125/iceri.2018.2379

[9] D. R. Blachford, B. Zhang. Rethinking international migration of human capital and brain circulation: The case of Chinese-Canadian academics, Journal of Studies in International Education, Vol. XX(X), 1-21, 2013.

[10] N. Day, J. Stilgoe. Knowledge nomads. Why science needs migrations, Demos, London, 2009.

[11] L. Ackers, B. Gill, J. Guth. Moving people and knowledge: Scientific mobility in an enlarging European Union, A Summary Report. European Law and Policy Research Group, Liverpool Law School, 2007.

[12] A. Cervinkovâ. „Postdokovat po svete“: genderové politiky akademické mobility, Gender rovné pfüezitosti, vyzkum, Vol. 11, No. 1, 49-59, 2010.

[13] M. F. Green. Measuring and assessing internationalization, NAFSA, Association of International Educators, Washington, DC, 2012.

[14] B. Wildavsky. The great brain race: How global universities are reshaping the world. Princeton, University of Princeton Press, NJ, 2010.

[15] E. Hazelkorn. Rankings and the reshaping of higher education: The battle for world-class excellence, Palgrave Macmillan, Basingstoke, UK, 2011.

[16] V. Bogoslovsky. Razvitie akademicheskoj mobil'nosti v mnogourovnevom universitetskom obrazovanii: metod rekomendacii dlya prepodavatelej [Development of academic mobility in multi-level university education: a recommendation method for teachers], St. Petersburg, Herzen State Pedagogical University, 2017.

[17] O. O. Martynenko. Otchet po proektu «Obobshchenie opyta uchastiya vuzov Rossijskoj Federacii v realizacii principov Bolonskogo processa» [Report on the project "Summarizing the experience of participation of universities of the Russian Federation in the implementation of the principles of the Bologna process"], Vladivostok, 2017.

[18] S. Tyrty. Formation of virtual mobility of higher school teacher in the process of professional development: abstract, dis. Cand. PED. Sciences, Rostov-on-don, 2014.

[19] H. Vossensteyn, U. Lanzendorf, M. Souto-Otero. Contributing to quality, openness and internationalisation -the Erasmus Impact Study 2008, in Higher Education Institutions in Europe: Mobilised by mobility?, University of Kassel, Kassel, 15-23, 2010.

[20] M. Souto-Otero, J. Huisman, M. Beerkens, H. de Wit, S. Vujić. Barriers to International Student Mobility: Evidence From the Erasmus Program, Educational Researcher, Vol. 42 No. 2, 70-77, 2013. DOI: 10.3102/0013189X12466696.

[21] A. M. Findlay, R. King. Motivations and experiences of UK students studying abroad, Dundee, UK, 2010.

[22] G. di Pietro, L. Page. Who studies abroad? Evidence from France and Italy, European Journal of Education: research, development and policies, Vol. 43, No. 3, 389-398, 2008.

[23] M. Souto-Otero, A. McCoshan. Survey of the socio-economic background of ERASMUS students: Final report to the European Commission, ECOTEC Research and Consulting, Birmingham, UK, 2006.

[24] F. Maiworm. Participation in ERASMUS: Figures and 
patterns, in ERASMUS in the SOCRATES Program, Lemmens, Bonn, Germany, 29-56, 2002.

[25] F. Maiworm, U. Teichler. The policies of higher education institutions, in ERASMUS in the SOCRATES Program, Lemmens, Bonn, Germany, 57-82, 2002.

[26] M. Fajó-Pascual, T. Sanclemente, A. Molina, S. Asún, R. Romero, J. A. Poblador, A. M. Ferrer-Mairal, E. M. Gómez, A. Vercet. Obstaculos para la movilidad académica con el programa Erasmus+: Diferencias entre grados universitarios [Barriers to academic mobility with Erasmus + programme: Differences between bachelor degrees], IV Congreso Internacional sobre Aprendizaje, Innovación y Competitividad (CINAIC 2017), Zaragoza, ESPAÑA, 2017.

[27] H. Vossensteyn, M. Beerkens, L. Cremonini, J. Huisman, M. Souto-Otero, B. Bresancon, N. Focken, B. Leurs, A. McCoshan, N. Mozuraityte, P. C. Pimentel Botas, H. de Wit. Improving participation in the Erasmus programme, Final report to the European Parliament, 2010, Online available from http://opus.bath.ac.uk/21174/

[28] C. K. Lane-Toomey, S. R. Lane. U.S. Students Study Abroad in the Middle East/North Africa: Factors Influencing Growing Numbers, Journal of Studies in International Education, Vol. 17, No. 4, 308-331, 2013.

[29] C. M. Sanchez, M. Fornerino, M. Zhang. Motivations and the intent to study abroad among U.S. French and Chinese students, Journal of Teaching in International Business, Vol. 18, No. 1, 27-52, 2006.

[30] E. Relph. Place and placelessness, Pion, London, 1976.

[31] H. M. Proshansky, A. K. Fabian, R. Kaminoff. Place identity: Physical world socialization on the self, Journal of Environmental Psychology, Vol. 3, 57-83, 1983.

[32] S. A. Shumaker, R. B. Taylor. Toward a clarification of people-place relationships: A model of attachment to place, in Environmental psychology: Directions and perspectives, Praeger, New York, 119-251, 1983.

[33] D. M. Chavis, J. H. Hogge, D. W. McMillan, A. Wandersman. Sense of Community through Brunswik's lens: A first look, Journal of Community Psychology, Vol. 14, 24-40, 1986.

[34] M. Prezza, M. Amici, T. Roberti, G. Tedeschi. Sense of community related to the whole town: Its relationships with neighbouring, loneliness, life satisfaction, and area of residence, Journal of Community Psychology, Vol. 29, 29-52, 2001.

[35] R. L. Rubinstein, P. A. Parmelee. (1992). Attachment to place and the representation of the life course by the elderly, in Place attachment, Plenum, New York, 139-163, 1992.

[36] G. H. Pretty, L. Andrews, C. Collett. Exploring adolescents' sense of community and its relationships to loneliness. Journal of Community \& Applied Social Psychology, Vol. 22, 346-357, 1994

[37] G. H. Pretty, C. Conroy, J. Dugay, K. Fowler, D. Williams. Sense of community and its relevance to adolescents of all ages, Journal of Community Psychology, Vol. 24, 365-380, 1996.
[38] S. V. Ryazantsev, T. K. Rostovskaya, V.I. Skorobogatova, V.A. Bezverbny. International academic mobility in Russia: Trends, types, state stimulation, Economy of Region, 2019.

[39] V. A. Iontsev, S. V. Ryazantsev, S. V. Iontseva. Emigration from russia: new trends and forms, R-Economy, Vol. 2, No. 2, 499-509, 2016.

[40] V. I. Skorobogatova. Spravedlivoe priznanie inostrannogo obrazovaniya: tendentsii, perspektivy [Fair recognition of foreign education: trends, prospects], Gosudarstvennyy sovetnik [The state counsellor], Vol. 1, 49-53, 2016.

[41] G. H. Pretty, H. M. Chipuer, P. Bramston. Sense of place amongst adolescents and adults in two rural Australian towns: The discriminating features of place attachment, sense of community and place dependence in relation to place identity, Journal of Environmental Psychology, Vol. 23, No. 3, 273-287, 2003.

[42] Education at a Glance 2016: OECD Indicators, OECD Publishing, Online available from https://www.oecd.org/edu/Education-at-a-Glance-2016.pdf

[43] Education at a Glance 2017: OECD Indicators, OECD Publishing, Online available from https://www.oecd.org/edu/Education-at-a-Glance-2017.pdf

[44] A. Gromov. Akademicheskaya mobil'nost' inostrannyh studentov $\mathrm{v}$ Rossii. Fakty obrazovaniya [Academic mobility of foreign students in Russia. Education Facts], No. 7, 1-15, 2016. 